This is an Accepted Manuscript of an article published by Taylor \& Francis in Journal of Cultural Geography on 06/10/16, available online: http:// www.tandfonline.com/doi/full/10.1080/08873631.2016.1231372 
The Monuments of Kings Cross: a visit to the new ruins of London

Nick Ferguson, March, 2016

Abstract

When in 1967 the American land artist Robert Smithson visited the New York neighbourhood of Passaic, he travelled from city centre to periphery. There, on the edge of town, he saw an entropic future. But would he have gone in the same direction, or looked in the same places, were he seeking a similar experience today? What if it is from the core that the metropolis now decays? What if, in an era of the global city, it is at the heart, rather than the extremities that the extraordinarily ordinary is to be found? The Kings Cross development in central London suggests as much and its vast incompleteness invites a reworking of Smithson's vision. This is the record of that undertaking. In an inversion of the Passaic narrative, the viewer is taken from one of London's outermost suburbs to the structures rising in its newest centre. Here, in the name of regeneration, and powered by corporate finance, the remains of an industrial past are being incorporated into reformed spaces of leisure and information. The urban transformation is skilfully choreographed. But written into the display, or enacted through encounter, are primordial instincts that not even marketing can sublimate.

Keywords: Monuments of Passaic; Kings Cross; ruins; regeneration; urbanism; psycho-

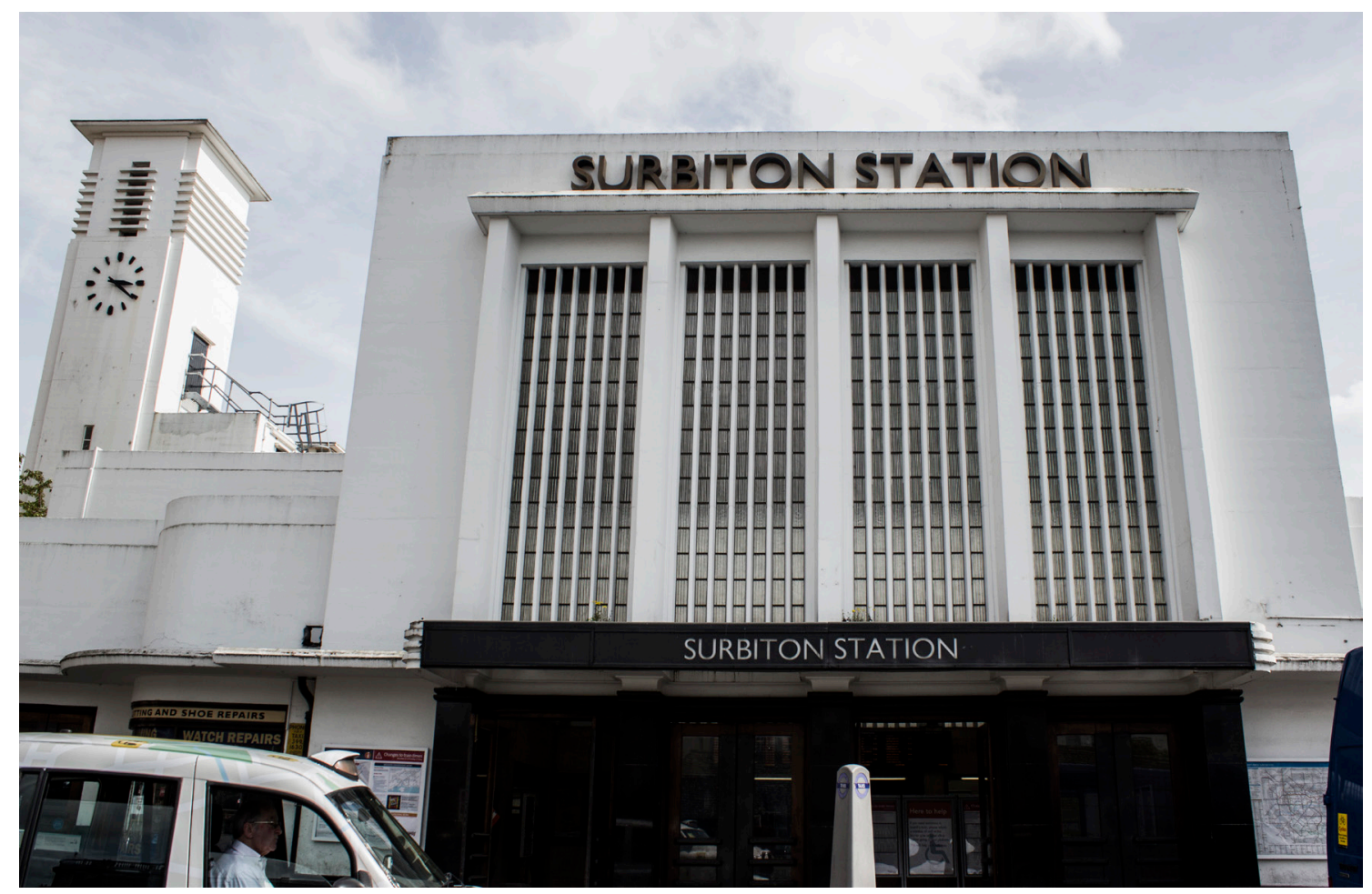


geography

On Friday 27th March, 2015, I went to the British Heart Foundation Charity Shop on St Mark's Road, Surbiton. I bought a signet paperback called Earthworks by Brian W Aldiss. I then went to the ticket booth in the train station, picked up a copy of the Evening Standard and bought a one way ticket to Kings Cross. I boarded a Waterloo bound train at 1.23 on platform 4 .

I would be contributing to a symposium on the Kings Cross development. In preparation I had decided to visit the construction site to the north of the stations and, by way of beginning, I would take a metaphorical bearing on the photo essay The monuments of Passaic by the American artist Robert Smithson. Published in the journal Artforum in 1967, Smithson's essay describes a journey from New York Central Station to the suburb Passaic, where he saw the decaying but perpetually incomplete suburb of Passaic as "ruins in reverse ... all the new constructions that would eventually be built" (Flam 1996, p. 72). How, though, I wondered, would Smithson's spatial thought stand up today? In a post-industrial metropolis, is it still meaningful to conceive of an inner and outer city? Indeed, in the era of the "global city" (Sassen 2001), to which both New York and London allegedly belong, is it possible to conceive of a centre at all? And is it still in the suburbs that, as Smithson showed, the extraordinarily ordinary is to be experienced, or where entropy first sets in? Or would I perhaps more easily recognise Passaic in Kings

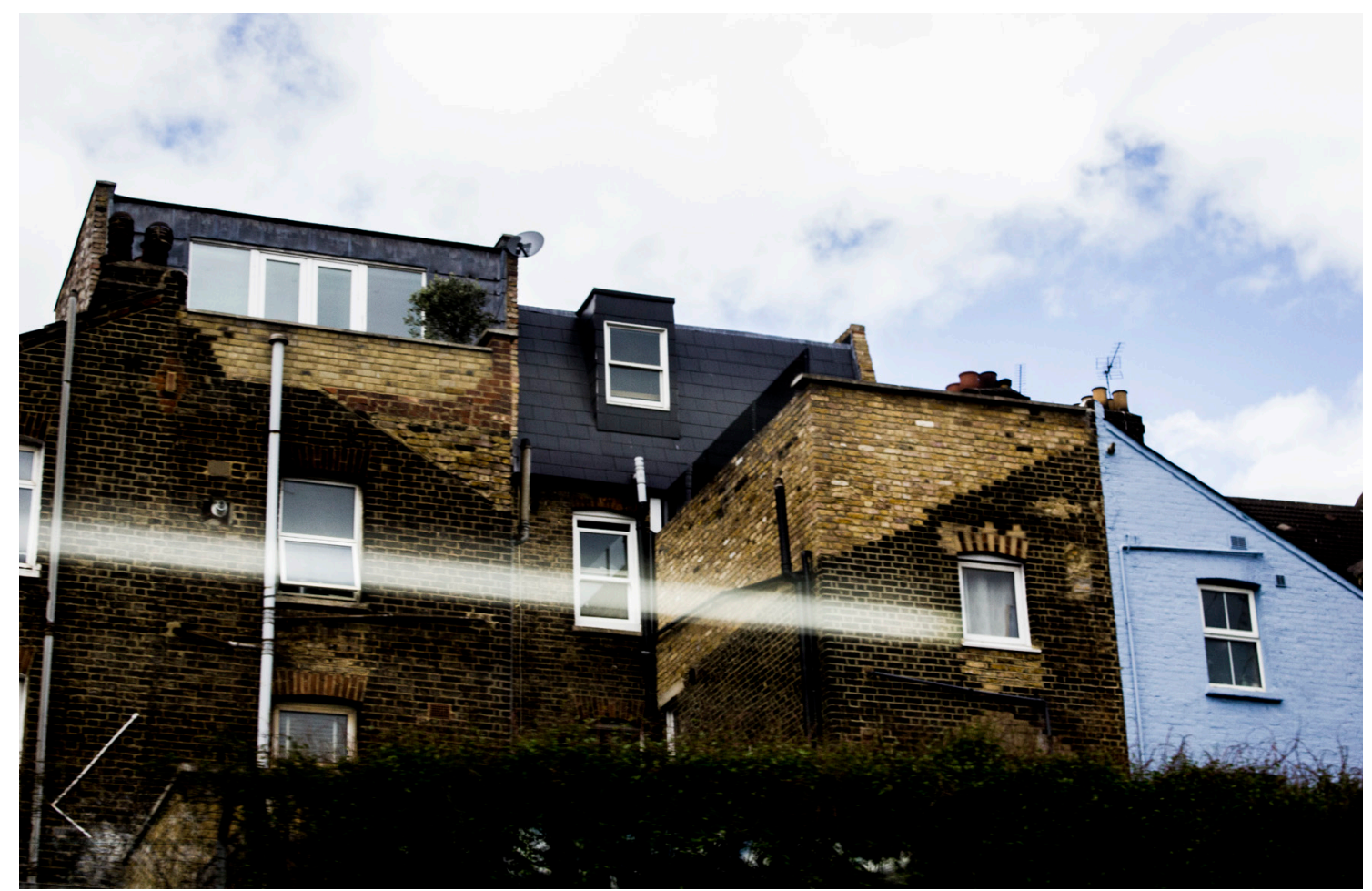




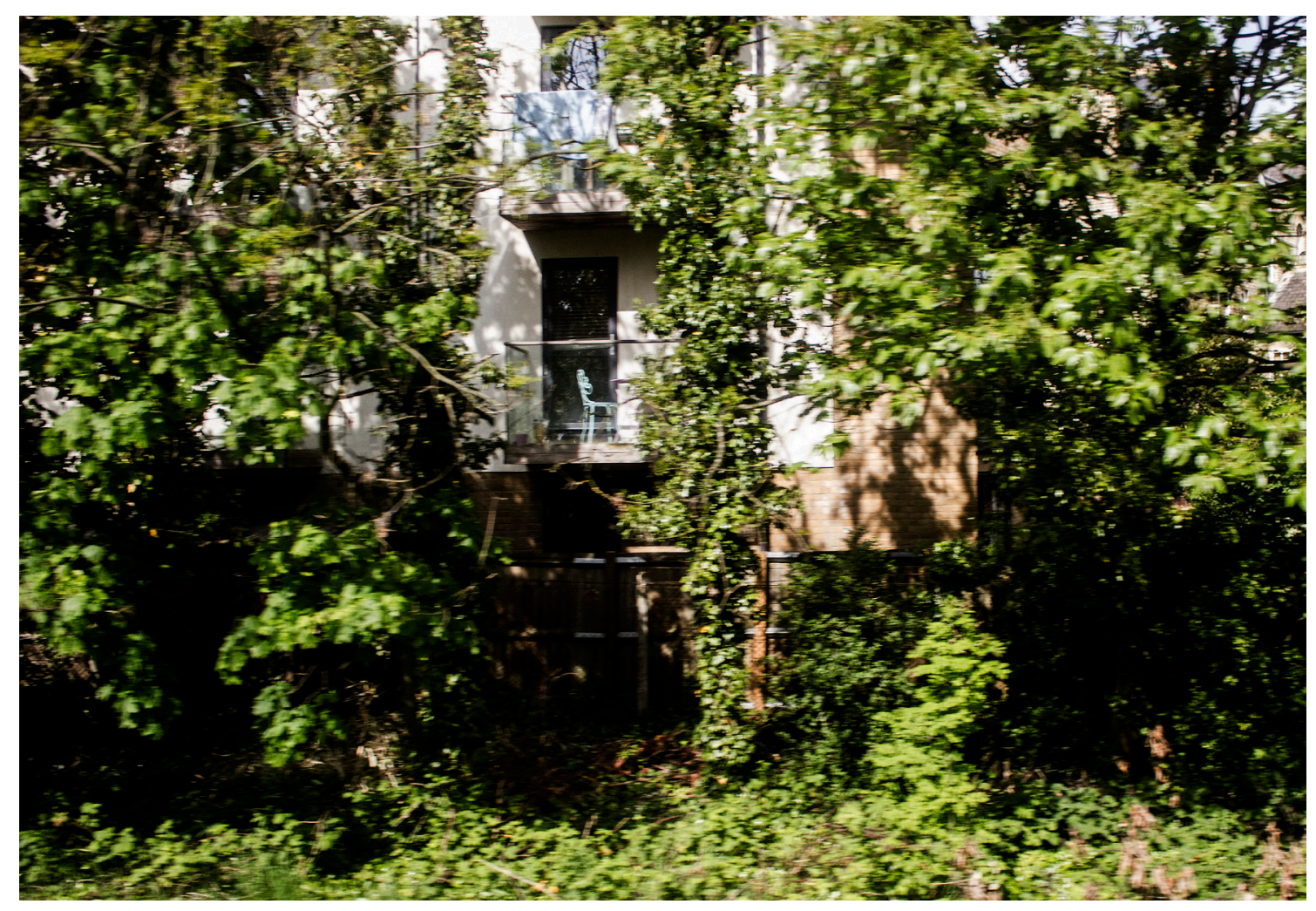

Cross than Surbiton? In which case, what narrative might unfold if, in aligning my trip with that of Smithson, I were to reverse the direction of the journey?

At Surbiton I was struck by the self-confidence of the station complex (Figure 1). Its facade spoke with authority, and the generous interior of the ticket hall disclosed a civic valour seemingly out of proportion to the town it served. As if placed too far out, Surbiton was waiting for the metropolis to reach it. At the cinema I'd noted that it was within this liminal site, somewhere between country and town, where Dumbledore has a chance encounter with Harry Potter and tries to persuade him to return to the Wizarding world (Rowling 2009). More ordinarily though, Surbiton is characterised as belonging to another kind of outside, namely a periphery place where the city's corporate insiders go in order to sleep, and who, during the day are whisked by train, along with their folded bicycles, into the eye of Waterloo Station.

I chose a rear-facing seat and as the train chugged eastwards I watched an unforeseen landscape recede before me. Some of the gardens that backed onto the line to New Malden were screened from the track by leylandeii trees (Figure 2). For the imagination that had composed these brutal views, the denial of publicness must have been total. Such modes of attention had once been typical here. When I rode past, the prospect was predominantly open and expansive, and even from the fleeting and fractured glimpses 


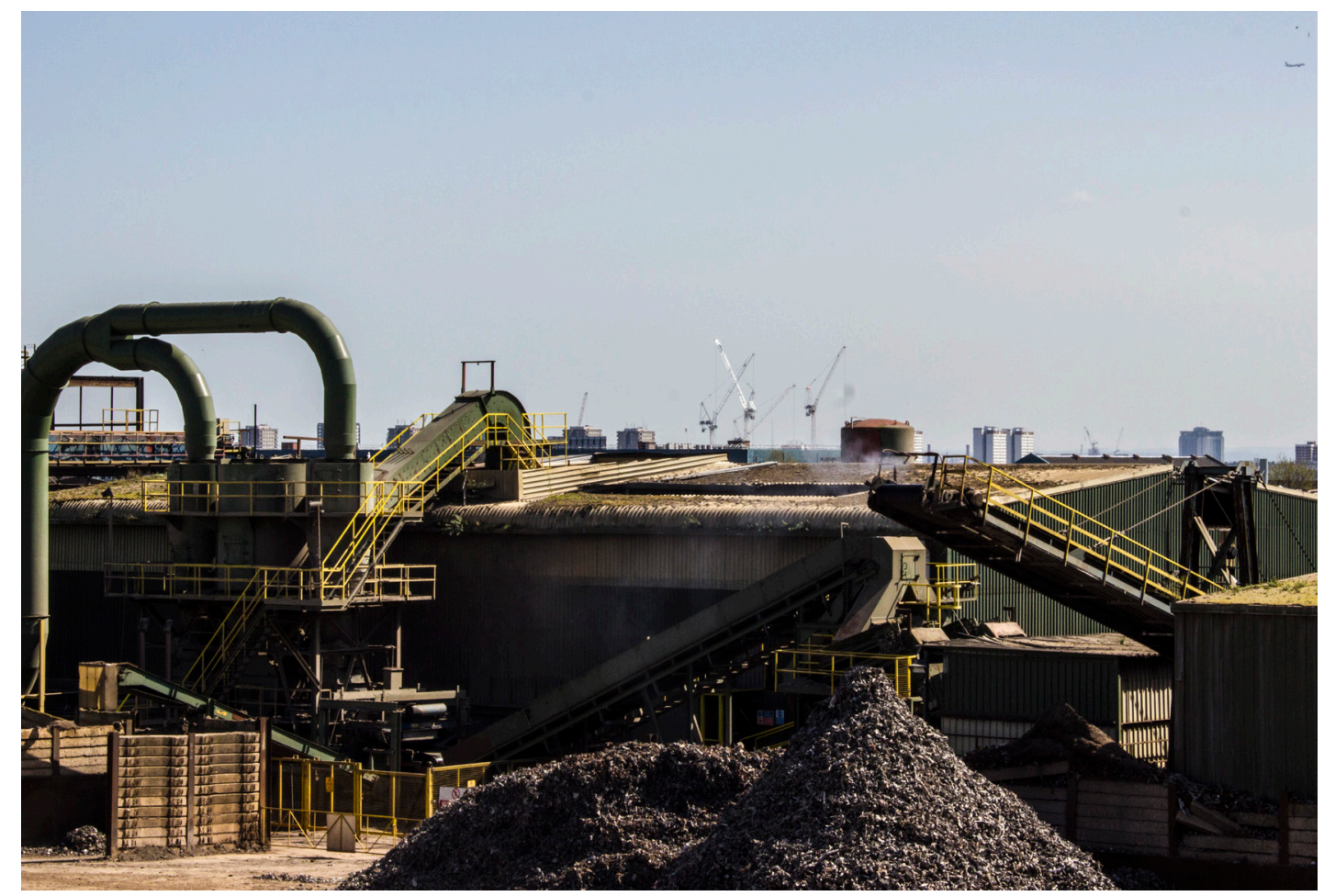

that my speeding viewpoint afforded, I saw that most dwellings were of mixed tenure. Many had loft extensions with full-frontage glass, and others had balconies that afforded a panorama of the line (Figure 3).

On a stretch where there were fewer trees I glimpsed a garden cleared of its grass. My view of it was momentary, but it left on my retina sufficient imprint for me to record that I had passed the site of an archaeological excavation. The topsoil has been removed and heaped alongside a broad but shallow pit in the bottom of which there was a concave circle of darkened earth. Scattered across the floor just next to it were small tools: a trowel, a brush, a tape measure and a wooden rod of about two meters in length and painted in red and white stripes.

In many of the gardens, normally towards the railway end, there were fruit trees. They were mainly apple - Bramley and Cox's Orange Pippin. Collectively these must have formed an orchard that ringed the city. If in the springtime you were to have stopped and smelt the blossom, you would surely have detected the hope of subsistence living, and perhaps even, if it were a still evening, lingering anxieties of the Cold War. On the day I passed, few of the trees looked pruned. Perhaps the inhabitants of the dwellings along this route had awoken from the languid time of waiting. 
Perhaps their metabolism had quickened and they had shed their reputedly dreamless and dour uniformity. I registered a mild disappointment to have been deprived of the promised banality (Wickstead, 2013). As little as ten years ago, the ripple caused by the city's flux and flow had been barely discernible here. It may yet reach Surbiton.

I had set myself the condition of travelling overland so that I could observe the cityscape the entire way. It had been clear from the online route planner that my journey would be an awkward one, with changes at New Malden, Richmond, and West Hampstead. London's railways were not planned for inhabitants to travel between these two locations. Indeed, if travelling by Overground train, it is now quicker to get to Kings Cross from Lille in northern France than from the London suburb of Surbiton. If made in on a weekday afternoon, the former journey takes 1 hour 21 minutes, the second 1 hour 45 .

At Acton Town I browsed the paper:

Police Mourn Sniffer Dog who Died after Inhaling Crystal Meth During Drugs Raid Google Loses Court Battle on Web Snooping, Opening Doors to Privacy Law Suits French Alps Crash: Co-pilot 'Hid Sick Note From Bosses on the Day he Crashed Germanwings Plane, Killing Everyone on Board'

London Landmarks to Mark Earth Hour by Switching Off Lights For 60 Minutes.

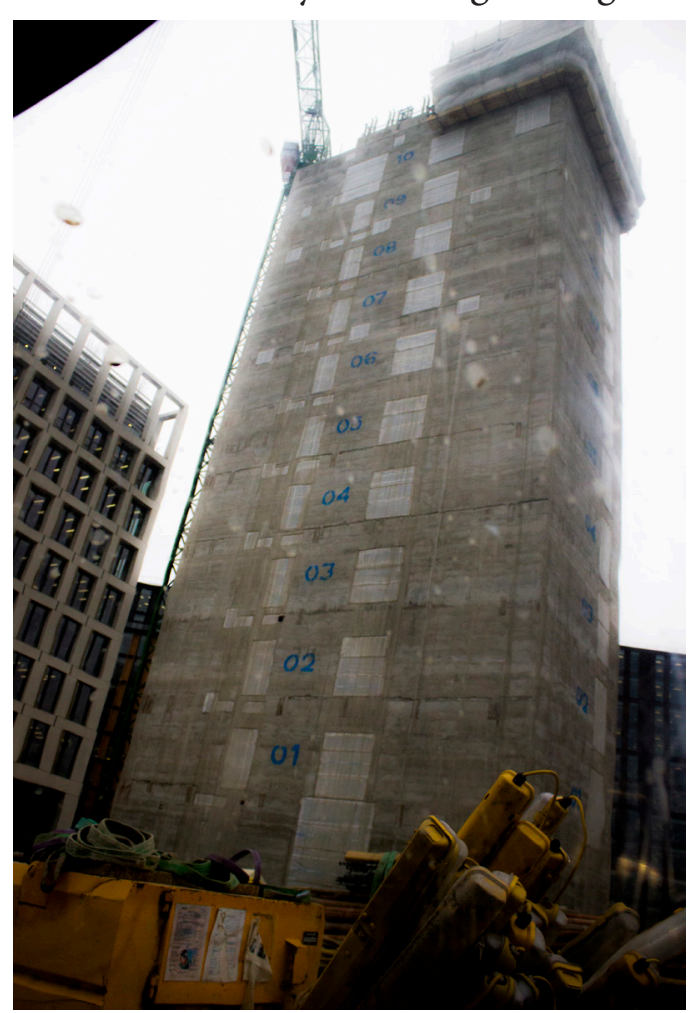


At Willesden Junction a message came over the public address. A lorry had hit a bridge at Camden Road and there would be severe delays. I stepped off the train and onto a footbridge that led to Car Giant, the used car supermarket. The bridge was high enough to afford a perspectival view of the cityscape. To the west- the direction from which I had come -stood a shipping container depot; to the East, a recycling plant and beyond it, towards the old city centre cranes (Figure 4). On the horizon, gleaming like a totem to technology, I could just make out the British Telecom tower.

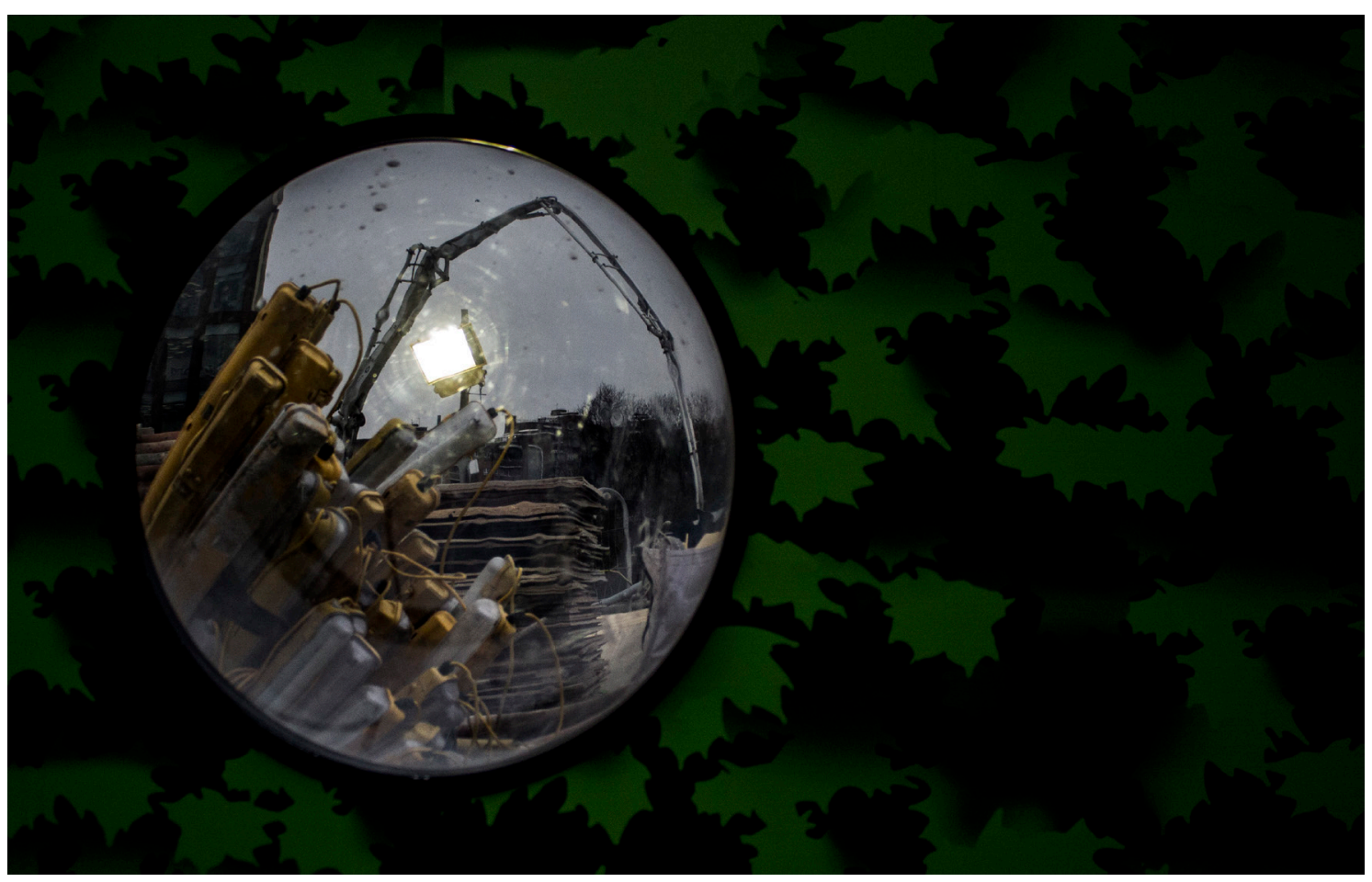

A number of years before my visit, around 2002, I had seen the Kings Cross site from the window of the Eurostar train as I arrived from Paris. It was a hinterland of railway sidings, coal sheds, gas holders, the machinery of a proud capital, once so precisely positioned to instil wonder and awe in the hearts of arriving and returning visitors from northern Britain. But the curators and financiers had long since departed. Artists had moved in. They say it was a hotbed of crime and prostitution. I thought I could make out the grimy bridge on which the actor Alec Guinness, cloaked in steam, had disposed of corpses in The Ladykillers (Mackendrick 1955). Today I glided with the crowd into 


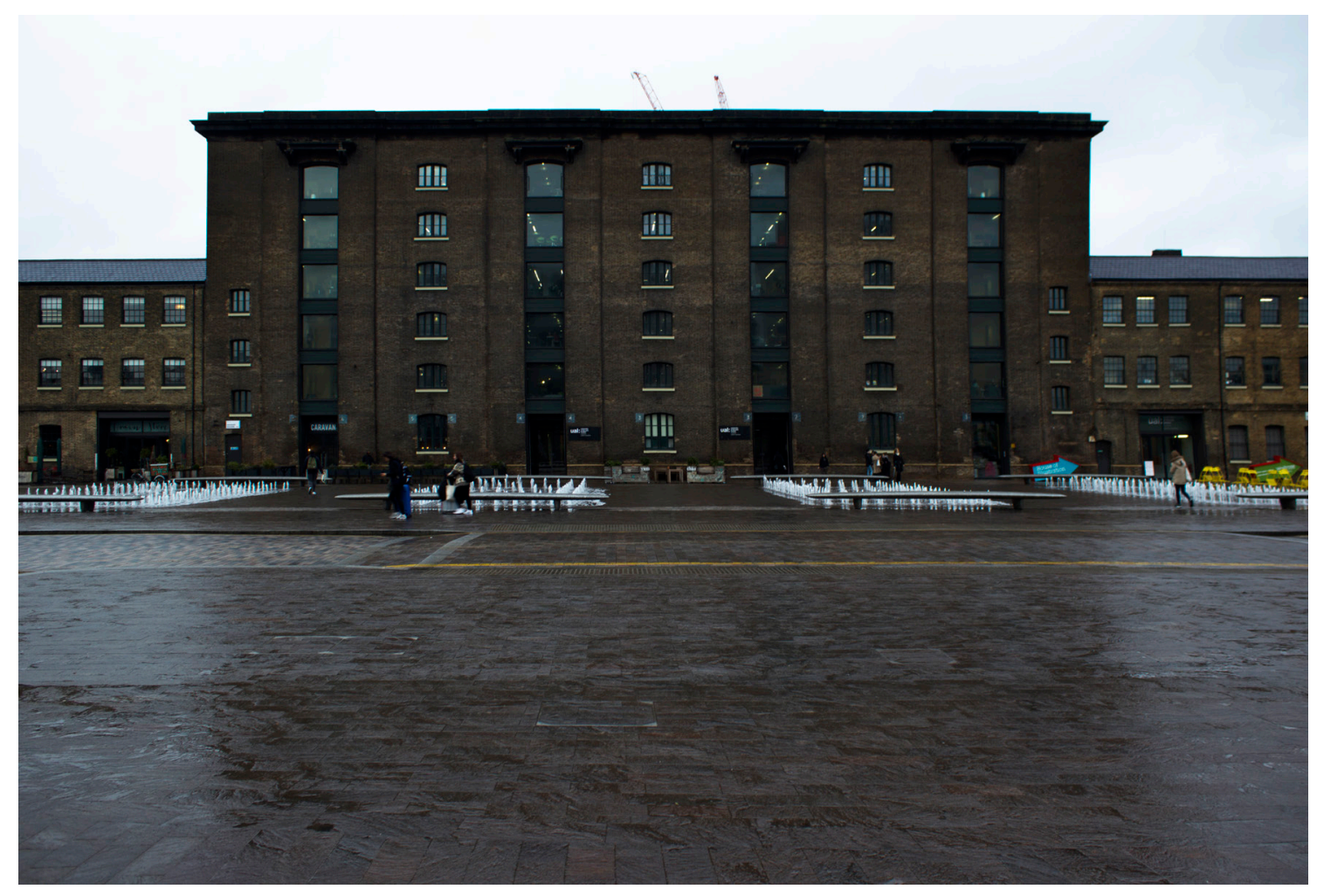

a glistening piazza where there was a Henry Moore sculpture titled Large Spindle Piece (Moore 1974) (Figure 5). There was a plaque stating that it was on loan from the Henry Moore Foundation, but the plaque did not specify to whom it was being lent. It was a bronze of a flint pebble. I wanted to call this sculpture The Track Ballast Monument, only Moore claimed indifference to the site of his work (Kwon 2004). I typed its title into the web browser on my phone, and learned from Wikipedia that there are copies in multiple locations including: the science quadrangle at Kenyon College in Gambier, Ohio; Eleanor Tinsley Park in Buffalo Bayou Park in Houston, Texas; Corniche Road in Jeddah, Saudi Arabia; Hakone Open-Air Museum in Hakone Japan. There was also a version, cast in travertine and slightly larger in scale, which formed the centrepiece of a fountain in the lobby of the Intercontinental Hotel, Miami. Prompted by my sustained curiosity, images of these casts and their environments, rapidly presented themselves on my screen.

I headed northwards, cutting between two giant terminal buildings, St Pancras to my left, The eponymous station to the right. I had read on the website of the new landowner, Kings Cross Central Limited Partnership (KCCLP) that there were to be ten new parks and squares, 20 new streets and 1900 new homes. (Kings Cross Business Partnership Ltd. n.d.). Since then Google has commissioned a new building, Google KX, and will occupy in 2016. The crowd thinned and I found myself on a pedestrian zone with paving so 

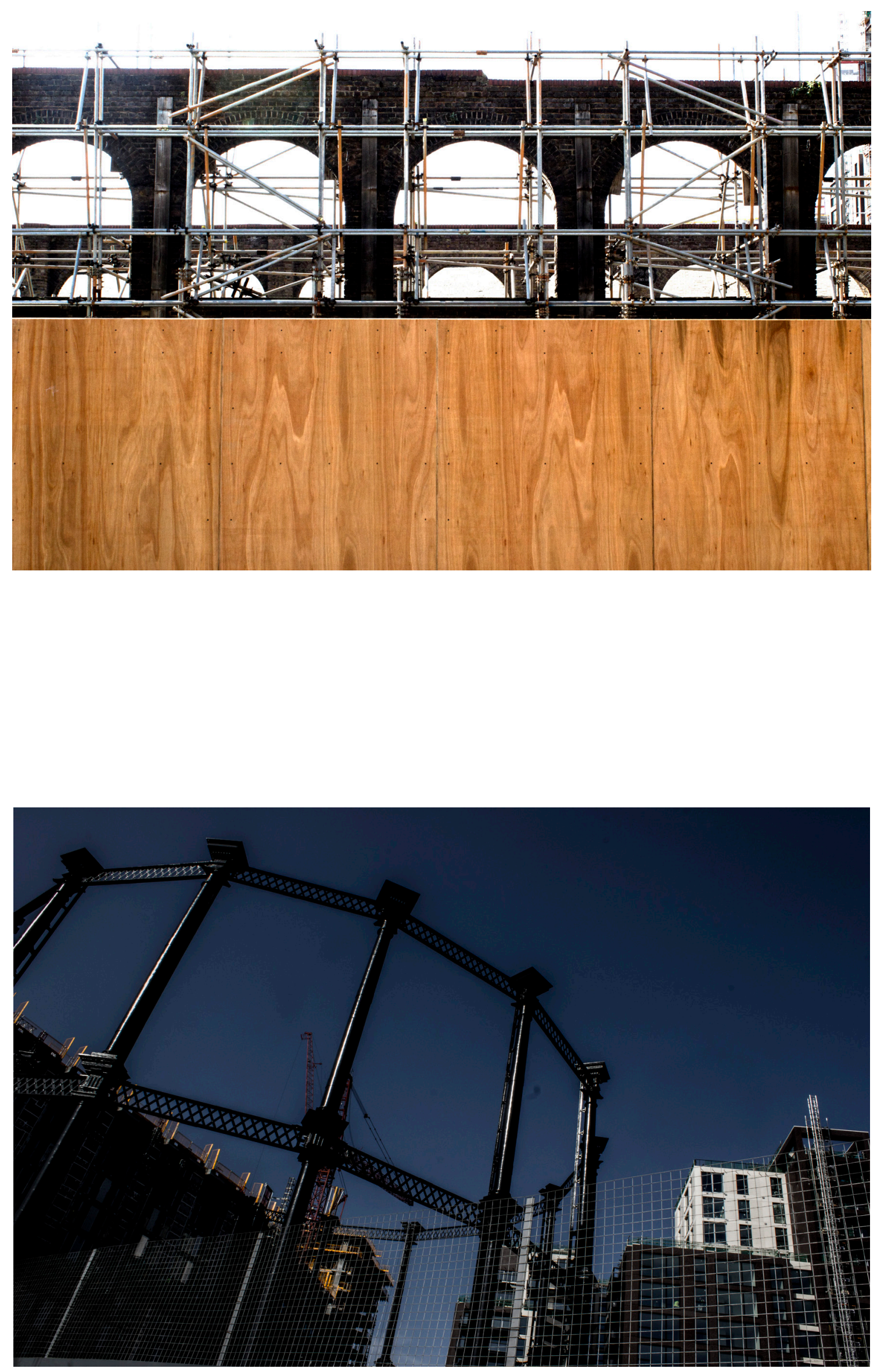

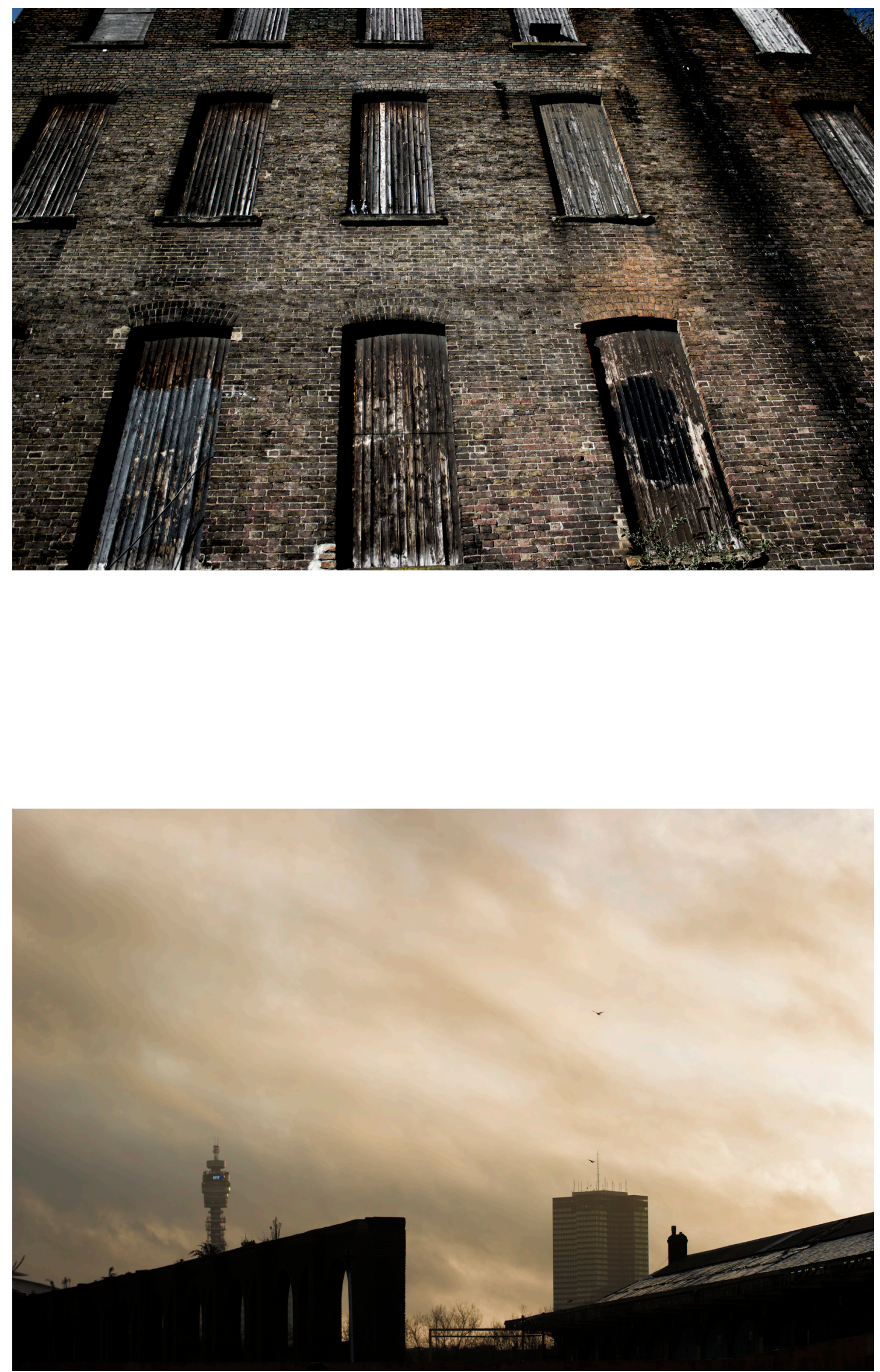
new that it was still uncontaminated by chewing gum and which narrowed to a corridor lined on both sides with plywood hoardings. The developer's public relations team had thought to print the surface with a green plane leaf pattern and a set of Enid Blyton heritage panels which informed us that this had been the setting for part of The Railway Children.

The Porthole Monument was a viewing facility a short walk along the corridor (Figure 6). I put my eye to one of a pair of circular screens set into the hoarding. The view through it was far from clear. The portholes were each fitted with a concave Perspex screen - something like those found in a washing machine door - but they had become coated with a film of fine dust. The granulated view revealed the silhouette of another monument, a concrete pumping pipe, which resembled the gigantic neck of a long-extinct reptile, only stripped of its skin. It shivered and roared as the concrete slid along its iron oesophagus, as if by reverse peristalsis, and it vomited into a gigantic trench in the ground. A number of workmen were guiding its pipe-mouth. This arrangement of screen and performance reminded me of a reality TV show and I wondered about the extent to which the activities I was witnessing might, however remotely, were being undertaken for my benefit.

Immediately to my west there were a number of Tower Monuments, sulky concrete shells without lights or windows, and with reinforced steel rods protruding at the top (Figure 7). They recalled the "abandoned set of futures" (Flam 1996, p. 72), more commonly found at a city's outskirts, or the incomplete constructions seen in developing countries where money and time and the will to go on have long since expired. This is not to suggest that the towers at Kings Cross are derelict in appearance only - so that they are one thing mistaken for another, though undoubtedly mistaken identity resulting from their unfinished state may serve them well. Legend has it that in Dhaka, Bangladesh, during the liberation war of 1971, the construction site of Louis Kahn's National Assembly was spared by bombers because they mistook the complex of primordial forms for the ruins of an ancient historical site (Kahn 2004.) In the global city post 9/11, misidentification with the politically benign is not a prospect to be overlooked. In the coming decades perhaps we will even see an architecture of thanatosis - buildings that are, as it were, pretending to be dead so that their chances of survival are increased. But if the structures at Kings Cross were ruined futures, this is because the development was, in advance of its completion, modernist. They belonged to a logic of total architecture, to mastery, and according to which, as Deepa Naik and Trenton Oldfield put it, people in the teams "don't propose projects upwards. They deliver projects passed down the chain to them" (Naik and Oldfield, 2010, p. 4). It is a way of thinking long abandoned by the reasonable, 

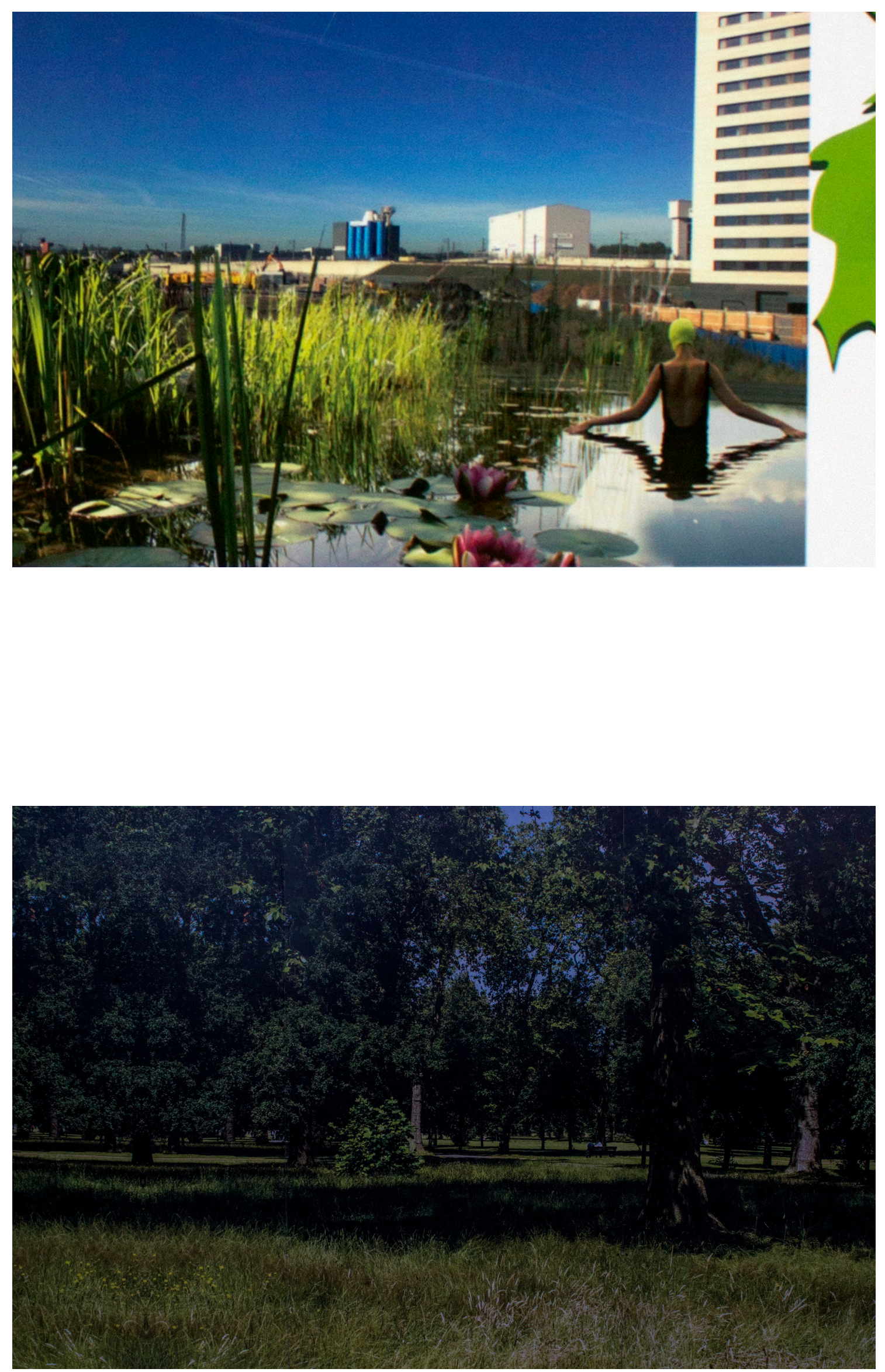
which not long ago had, from a European point of view, been permitted only in out-ofthe-way places.

I resolved to resist the corporate future that I was promised in this corridor, though what form my dissent might take I did not yet know. I would need to get behind the interminable façade to a place less scripted, less legislated, and where I might benefit from direct experience, uncertainty, risk. I crossed a canal and was drawn across a windswept square to a major monument. The Art School Monument (Figure 8). But the boundary from which this centrepiece began its "presencing" (Heidegger 2001, p. 153) told me at once that it could not serve my purpose. In front of it there were fountains - multiple jets laid out in rows - that functioned at once as ornament and fortification. The windows predominantly faced into internal concourses, as if its occupants preferred not to be connected to the world outside. The entrance to the innermost of these was guarded with stainless steel turnstiles.

The hoarding that ran alongside the western side of the Art School Monument was finished in an oiled hardwood (Figure 9). At the point where it terminated the path was flanked by a kind of moat, only there was no water. The primary function of the hoarding along this stretch was to conceal a shipping container that served as a site office. The door had been fitted with a gold-plated keypad lock, but it was unclear whether the gold finish (rather than the more widely used silvered version) had been chosen to signal the status of the occupant of the office to which it barred unsolicited entry, or the stylishness of the "arcade" onto which the office opened.

To follow the hoarding northwest along the Regent's canal I had to pass along The Floating Walkway Monument (Figure 10). It lurched and swayed with constant footfall, so that the horizon rose and fell as I surveyed it. I was able to produce an in-focus photograph by increasing the camera's shutter speed, though no sharp observation could be made by eye. A short distance along the canal was a lock and opposite, to the right of the towpath, stood the iron frame of a Gasometer Monument (Figure 11). It was, I would discover later, one of four that had been relocated to the canal side from another part of the site. The cylinder described by the frame was now being filled with apartments, so that the internal chamber which had sunk as it emptied was rising into dormitories. I wondered whether or not new residents would find it soporific to think of themselves in a space once reserved for Camden's gas.

It was not possible to continue on foot around the boundary of the development. The hoarding butted resolutely against a railway bridge at a point where there was a pungent smell of fox urine. But it was here, in the right angle between the two structures, that I 
saw the footholds that would serve my purpose. Within a few seconds I had dropped to the ground on the far side and was standing on an area of exposed earth about the size of a football pitch. Excavated soil stood in mounds and I found myself asking whether the gobbets of clay, resting as they did on gravel, and in turn, bedrock and tectonic plates, might constitute the specificity of the site. Did this arrangement perhaps open up new ontologies for the Henry Moore by the station? Before I had time to reflect further, a group of workers caught my attention. They had formed a circle on a patch of ground about fifty meters from the fence and, after removing their gloves, took turns to scoop at the clay with their bare hands. By now the afternoon was wearing on and the light beginning to soften, but if I am not mistaken I saw one of them shape the clod he had gathered into a ball, transfer it to the palm of his left hand and squeeze it till it oozed between his fingers. I watch him repeat this act twice as others looked on. So taken back was I by the ritual that I failed to notice the security guards who were moving towards me along the inside of the near fence. There is a shout, a brief commotion as the protagonists respond to the interruption and, without warning, they are nearly upon me.

The experience of ruin at Kings Cross is complicated along the Regent's canal by the presence of historical ruins. The path along which I sprint takes me past the debris of empire: leaking sluice gates; a rusted barge; railway arches sprouting elder and groundsel,

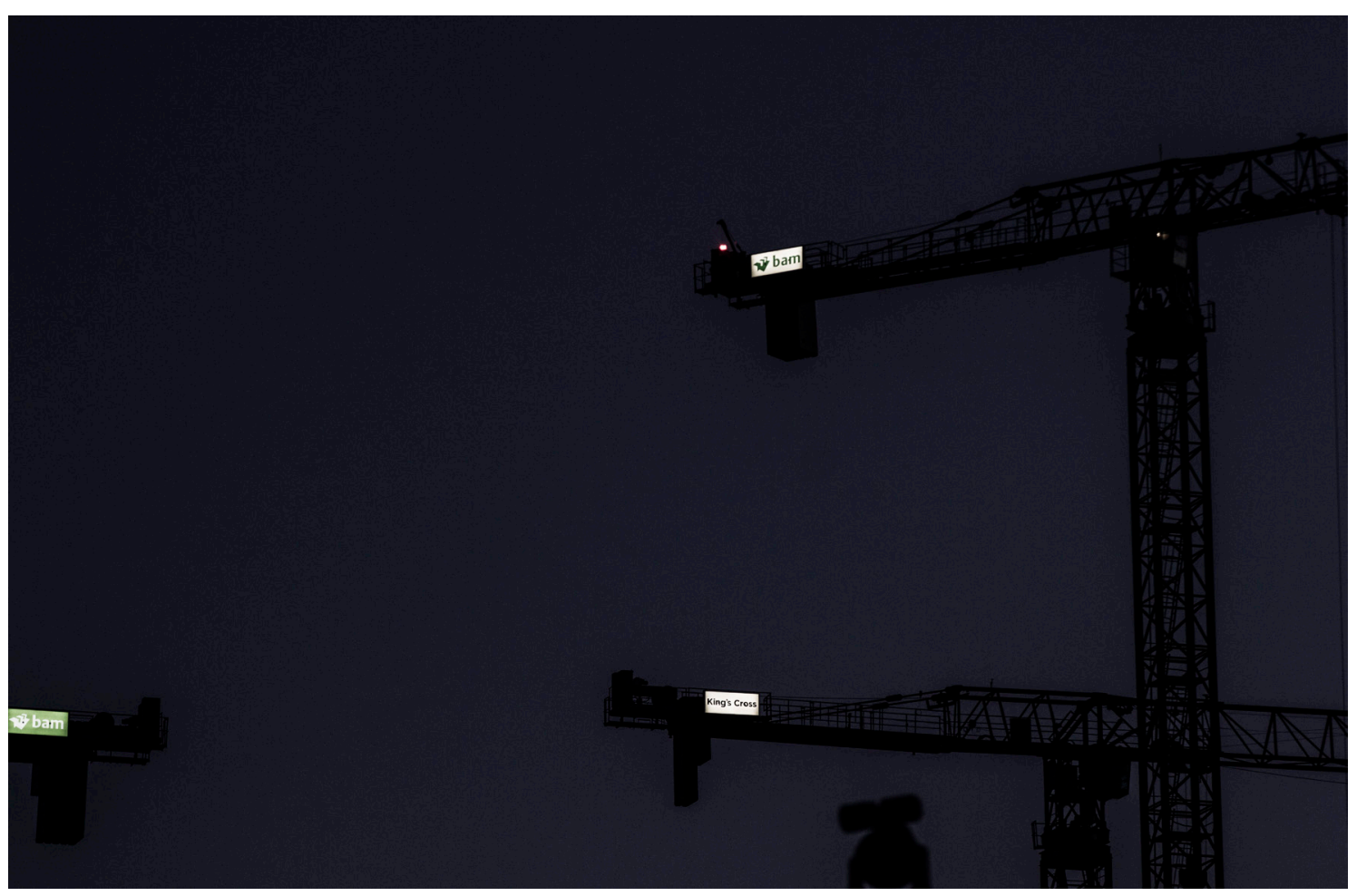


brick warehouses eroded by the years and the seasons (Figure 12). Here is a landscape of dead labour. If its Victorian architects ever had a penchant for the Gothic, their creations have finally come into their own. From the willowed bank on the far side of the canal there is the call of a coot, as if conspiring to add a touching sadness to the scene. But unlike the new constructions, whose skeletal appearance anticipates their entropy, these owe their continued existence to their having resisted the ceaseless flux of the metropolis. They are the survivors who have evaded the wrecking ball of progress. Having made it so far, rather than being pulled down to make way for the new, as is happening in so many other parts of the city, they are, perhaps paradoxically, in the process of being incorporated into the development. They will be official ruins - part of a new story that the city will tell about itself.

In several of the arches workers have begun the Sisyphean task of raking out the weathered lime mortar. They are scraping it brick by brick, while not far behind them bricklayers are replacing it. It is clear from the extent of the surface already covered that they have been at this activity for many months. At some point every joint will have been quantified and accounted. Little by little, the minute differences in mortar mix that has born witness to the evolution of the structures, to their periodic repairs over the passage of time, and which has thus made the past legible, are being irretrievably erased. At some point these buildings will all, both physically and visually, be bound together into a coherent and cohesive whole of what might be called ruin value. Once finished, they should enchant the development's ordinariness and indulge visitors in a fetish for the archaic rather than anxieties (or is it a thrill?) about a dystopian future. The photogenic 'old' will also provide a kind of spacing - temporal as well as Euclidean. It will serve to punctuate the development to create an illusion of what Kenneth Frampton called nearness (Frampton, K, 1980); a fancy that the corporate present is rooted in an industrial past; an impression of diversity - antagonism even - strategically incorporated to reassure the sceptic that this is an urban space: gritty, irrational, indeterminate.

From the top of the hoarding I clamber back down to the towpath and returned to granary square. Caught on the inside, and without a door onto the canal, the security guards have not, in the event, given chase. Instead, as I shall discover, they have radioed to their colleagues - perhaps they had been resting in the Portacabin behind the gold-plated keypad - and requested that I be tracked by means of closed circuit television. Ignorant of the attention that I continue to command, I skirt anticlockwise round the Art School Monument, passing a pristine Basketball Court Monument to the north east, and from here, confident of my anonymity, I begin to track back towards the canal. It is at this point that I encounter the earthworks that are to be part of the Pond Monument, a piece 
of public art that, according to a notice attached to the hoarding, is behind schedule.

The evening is now advancing but the fading of the sky is more than compensated by the saturated colour print of a CGI drawing pasted to the hoarding (Figure 13). To record it, I am able to increase the light sensitivity of my camera. In the foreground there is a figure - female - standing thigh deep in an area of the pool where she is clear of reeds and aquatic flowers. She has her back to the spectator as if in an invocation of The Monk by the Sea (Friedrich, 1810). Behind her, in the distance, and in view of the pool, there are, rendered in an electric blue, the storage chambers of a cement factory. It is as though the industrial feature is entirely commensurate with the urban lifestyle promised by the pond. There is also a quality about the pool - and this is undoubtedly enhanced by the otherworldly colours of the digital print and the end of day in which it is now bathed - that is suggestive of a primordial swamp, to which the bather is now ceremoniously returning. An information panel explains it all. Part of it reads:

"The Pond was designed by architects Ooze and artist Marjetica Potric as part of Kings Cross public art program "Relay". It went on: "This thought provoking installation makes its audience experience the relationship between natural and built environments by the permanence of the buildings and, contrastingly, the changing nature of undeveloped spaces."

This is as much of the account as I get to register: my whereabouts has been pinpointed and security guards are once again coming my way.

My first glimpse of The Forest Monument is through twilight, from a distance and as I am on the move (Figure 14). There are dog walkers and quotidian couples picnicking in the shade of the trees. The park promises open space and once inside, I shall hide in the shadows of an oak, of which I can now make out the gnarled and aged trunk. I am already beginning to relax and find time to wonder what made me run rather than turn and talk. Is there something about the location that has excited my sense of transgression, so that in this place I know only how to misbehave?

Now as you may already know, the park is not a park at all. Rather, it is another section of hoarding, this time several hundred meters long and to which has been pasted a super-length billboard photograph depicting managed woodland. It recalls Richmond Park, not far from where I have started out earlier in the day. Under the faint glow of the sodium sky I almost slam straight into its glossy surface. It is only a yellow notice floating on the surface that saves me from injury. My pursuers are now on my tail and I hear the Slavic tones of their radio requests for reinforcements. I turn the corner to the right, 
follow the hoarding and arrive at a door in one of the trees. I am through it in a flash, and find myself under the fluorescent light of a public toilet. On the washstand lies a discarded high visibility jacket, on the back of which is printed the letters "B A M". I waste no time in slipping it on, before emerging into the darkness to join the search.

The corridor comes to a road, at the intersection of which I encounter the Viewing Platform Monument. This would seem to have taken its principle from Christopher Wren's Monument on Pudding Lane. This version at Kings Cross consists of a platform supported on two shipping containers and raised to approximately six meters. The structure is clad in plywood and takes the overall form of a white-painted cube, the simplicity of which is suggestive of an Italian minimalist architectural form - maybe Aldo Rossi's Monument to the Resistance.

From the top of the platform I see to the north the art school presiding over the neighbourhood like a cultural acropolis. To the south a panorama of the city. This is accompanied by a site-sized line drawing of the type provided at tourist destinations that have iconic views. It shows, in rationalised form, the same landscape as I can already see. In the centre are the glass and steel arches of the great railway station and to the right the redbrick clock of St Pancras. To this is attached a label denoting structures, not all of which are strictly visible. It says:

ST PANCRAS

INTERNATIONAL STATION

ST PANCRAS RENAISSANCE HOTEL (LEFT)

GREAT NORTHERN HOTEL

(HOTEL, BAR, RESTAURANT (RIGHT)

To the left of this is another building and its label:

TWO PANCRAS SQUARE

130,000 SQ FT OFFICES

To the right of this:

SIX PANCRAS SQUARE 
350,000 SQ FT OFFICES

BNP PARIBAS REAL ESTATE

As I look I see a boundless spread of structures that appear, both in reality and in their graphic representation, only partially built. Spaced throughout this vast and perpetual incompleteness stand huge cranes (Figures 15 and 16), each one doubling as a hinged hoarding that, like ancient beacons lit by the victorious, rhythmically proclaim across the skyline the names of their developer-heroes:

SHAFTESBURY

PERSIMMON

ST GEORGE

ST JAMES

WESTCOURT

BERKLEY

BAM

SIR ROBERT McALPINE

CARILLION

LOGON

GALLIARD

MACLAREN

TAYLOR WIMPEY

BOVIS

WAITES

POTAIN

BOUYUGES 


\section{BROOKFIELD MULTIPLEX}

I read the names out loud and as I do so I also observe that the nearer the cranes are to me, the greater their concentration, to the extent that they seem as if they are organised around a magical and invisible vortex, the eye of which cannot be far from where I am standing.

Notes

$\mathrm{n}$ version of this essay was given as a slide talk at the symposium In this neck of the woods, Central St Martins, London, June 4, 2015.

The monuments of Passaic was reprinted as A tour of the monuments of Passaic, New Jersey. In: Flam, R. ed., 1996. Robert Smithson. The Collected Writings. Berkley and Los Angeles. University of California Press, pages 68-74.

Compare also Smithson's quotation of Vladimir Nabokov: "The future is but the obsolete in reverse". Smithson. R. 1966. Entropy and the new monuments. In: Flam, J. ed., 1996. Robert Smithson. The collected writings, Berkley and Los Angeles: University of California Press, pages 10- 23

Smithson's journey began by bus. In the interests of arriving in Kings Cross in the manner for which the neighborhood had been designed, my re-enactment took the liberty of beginning by train.

For a brief survey of the stereotypes of Surbiton in British popular culture see Wickstead, H. 2013. 'Heritage and Folklore in an English Suburb'. In: Dines, M and Vermeulen, T. 2013. New suburban stories. Bloomsbury, pages

"Once I have been asked to consider a certain place where one of my sculptures might possibly be placed, I try to choose something suitable from what I've done or from what I'm about to do. But I don't sit down and try to create something especially for it". Henry Moore, quoted in Henry J Seldis. 1973. Henry Moore in America, New York: Praeger, 176 - 177. Cited in: Kwon, M. 2004. One place after another. Site specific art and locational identity. Cambridge Mass: MIT, page 63.

For Google's proposed new European headquarters see the architects' website Alford Hall, Monaghan Morris [online] Available from: http://www.ahmm.co.uk/projectDetails/116/Google-KX/ [Accessed 6 Jun 2015]

Smithson wrote: 'Passaic seems full of "holes" compared to New York City, which seems 
tightly packed and solid, and those holes in a sense are the monumental vacancies that define, without trying, the memory traces of an abandoned set of futures. Such futures are found in grade B Utopian films, and then imitated by the suburbanite.' Smithson, R. 1967. 'A Tour of the monuments of Passaic, New Jersey'. In: Flam, J. (ed.) 1996. Robert Smithson. The collected writings. Berkley and Los Angeles: University of California Press, page 72.

Earlier in the same documentary Louis Kahn is described by his son, Nathaniel Kahn, as wanting "to build modern buildings with the feel of ancient ruins". Kahn. N. 2004. My architect. A son's journey. [DVD]. New Yorker

Here I am thinking of the modernism of Le Corbusier's Chandigarh in northern India, or Oscar Niemeyer's Brasilia, Brazil, both completed in 1960.

The Monument (1677), in the City of London, provided a view from which to survey the city that was replacing that had been destroyed in the Great Fire of London, 1666.

The Monument to the Resistance, 1962, (unrealized), was to be a memorial on a ridge in Cuneo, Northern Italy, to commemorate local resistance to the German advance. Visitors would climb up inside the memorial and look across the landscape that had been defended.

References

Flam, R. ed., 1996. Robert Smithson. The collected writings. Berkley and Los Angeles: University of California Press.

Frampton, K. 1980. Modern architecture. A critical history. London: Thames and Hudson.

Friedrich. C. 1810. The monk by the sea. Oil on canvass. 110 x $171 \mathrm{~cm}$. Alte Nationalgalerie, Berlin.

Heidegger. M. 2001, Building dwelling thinking'. In: Heidegger, M. Poetry language thought. Trans: Albert Hofstadter. New York: Harper Perennial Classics, pages 143-159

Khahn. N. 2004. My architect. A son's journey. [DVD].New Yorker

Kings Cross Business Partnership Limited. n.d. Discover Kings Cross. [online]. Available from: https://www.kingscross.co.uk/discover-kings-cross [Accessed 4 Apr 2015] 
Naik, D and Oldfield, T. 2010. The urban industry and its post critical condition. In: Naik, D and Oldfield, T. eds., 2010. Critical cities. Volume 2. Ideas, knowledge and agitation from emerging urbanists. London: Myrdle Court Press, pages 3-27

Mackendrick, A. 1955. The ladykillers. UK: Rank

Sassen. S. 2001. The global city. New York, London, Tokyo. Princeton and Oxford: Princeton University Press.

Rowling, JK, 2009. Harry Potter and the half blood prince. [DVD] Heyday Films

Figure Captions

Figure 1. Surbiton Station. Front elevation. March 27, 2015. Photograph by author.

Figure 2. View from the train, New Malden, London. March 27, 2015. Photograph by author.

Figure 3. View from the train, Teddington, London. March 27, 2015. Photograph by author.

Figure 4. View from the train. Willesden Junction. London. March 27, 2015. Photograph by author.

Figure 5. Henry Moore. 1974. Large spindle piece. Kings Cross. April, 2015. Photograph by author.

Figure 6. View through The Porthole Monument, Kings Cross. March 27, 2015. Photograph by author.

Figure 7. Tower Monument seen through The Porthole Monument, Kings Cross. March 27, 2015. Photograph by author.

Figure 8. The Art School Monument. March 27, 2015. Photograph by author.

Figure 9. Hoarding of oiled hardwood, Kings Cross. March 27, 2015. Photograph by author.

Figure 10. Floating Walkway Monument, Kings Cross. March 27, 2015. Photograph by 
author.

Figure 11. Gasometer Monument, Kings Cross. March 27, 2015. Photograph by author. Figure 12. Historical Ruin, Kings Cross. March 27, 2015. Photography by author.

Figure 13. Section of hoarding with a CGI photograph of the Pond Monument, Kings Cross. March 27, 2015. Photograph by author.

Figure 14. Section of The Forest Monument, Kings Cross. March 27, 2015. Photograph by author.

Figure 15. Kings Cross skyline. March 27, 2015. Photograph by author.

Figure 16. Kings Cross cranes March 27, 2015. Photograph by author. 